\title{
Investigation and Countermeasure Research of Oral Medical Students Employment
}

\author{
Xu Yang ${ }^{1, a^{*}}$, Yanjie Liu ${ }^{1, b}$ and Defei Wang ${ }^{1, c}$ \\ ${ }^{1}$ Luohe Medical College, Luohe 462002, China \\ a78131193@qq.com, b526774603@qq.com, ${ }^{c} 1005231343 @ q q . c o m$ \\ *The corresponding author
}

\begin{abstract}
Keywords: Oral medicine; College students; Employment
\end{abstract}
\begin{abstract}
To medical students' employment difficult this social hot topic as the breakthrough point, to luohe medical college oral medical specialties, for example, from the state, school, family and college students themselves and so on investigation and research, the practical problems of university students' employment difficulties, puts forward the countermeasures and Suggestions to solve the problem of university students' employment. Combined with the characteristics of college medical students employment questionnaire design. Through the school of oral medical graduates employment problems of questionnaire survey, individual visits and employment units. Specific analysis of medical students' employment problems and restricting factors, put forward effective countermeasures and Suggestions.
\end{abstract}

\section{Introduction}

Since the late $1990 \mathrm{~s}$ since the enrollment expansion of higher education in our country, graduates of colleges and universities has expanded year by year, at the same time our country to realize the independent career for college graduates and the two-way choice, the problem of employment of college graduates, college students employment problem is not only related to the vital interests of the university and college students, but also a matter of reform, development and stability of the nation's major livelihood issues. College students' employment problem in colleges and universities has become a hot social concern, but also the difficulties of the government and colleges and universities.

\section{The Research Object and Methods}

This research takes the form of questionnaire and individual interview. Randomly selected from the three-year college students, oral medicine major of college students surveyed a total of 400 people. The student good style of study, take an active part in national vulture tooth (teeth) games, won the third prize in 2014, two in 2015 won the first prize in the national second prize two, one, two won the third prize in 2016. Questionnaires of 400 copies, recycling questionnaire, 390. (the questionnaire recovery rate of $97.5 \%$ )

\section{The Dental Professional Obtain Employment Situation Analysis}

Always pay attention to the problem of employment of college students in our country, the employment of college students is a matter of national future and national hope, graduate employment problem is not only a personal development problem, also reflect the level of education, more can reference to the economic development and social stability. Jiang Ziteng[1] on the university students' employment problem was analyzed, including the social environmental factors, such as market demand, such as national policy; Zhang Faqin[2] referred to the current employment disadvantaged problems exist in the process of female college students in employment, mainly is the influence of the traditional gender situation, imperfect social security mechanism, and female employment concept of college students themselves. Du kang[3] in the study, points out that led to the employment of the students in the process of the reasons of the existence of gender 
discrimination are various, such as college students' personal, unit of choose and employ persons, professional characteristics, etc. Yang Hui[4] investigation found 80 female college students' employment rate is low, the gender difference is bigger, the university after the specialized subject graduates of 80 men and women sex differences in college students' employment rate. There are many scholars [5, 6] from the Angle of other employment situation analysis, and put forward different views and opinions. Survey results show that the unit is the graduates is generally accepted that ideal job: municipal hospitals, schools, medical and health institutions (above city-level). As a medical professional, the professional is very strong, the students' employment choice focus or stay in the hospital, city, county hospital is the first choice for everyone, because students think that in the city, county-level hospitals can have more development opportunities and faster accumulation of experience and high pay levels, thus city, county-level hospitals won the favor of more than half of the graduates. At the same time, because the mouth can be independent operation characteristics, and some students after graduation to accumulate experience after starting my own business.

\section{Oral Medical Students' Employment Problem Analysis}

With the development of market economy, people become more and more attention, for oral health social demand for oral surgeons are bigger and bigger. Most parents think oral surgeons employment threshold is low, easy to find a job, therefore, oral medicine increase year by year, the number of college graduates in combination with the market demand, the college students themselves as well as the colleges and universities and the society various reasons in the current oral college student number, the difficult employment problem. Now from the following several aspects analyze the causes of college students' employment problem.

Blind Expansion by Graduates Imbalance between Supply and Demand. As a result of college expansion and social demand the emerging post the contradiction of insufficient, college graduates' employment problem is becoming more and more prominent. In recent years, increasing year by year college graduates enter the society, in order to better help college students employment, the government also introduced policies, job creation and encourage entrepreneurship to create more employment opportunities, but face the huge crowd, graduation is still obvious contradictions.

Graduates Over-Expectation, Nowadays. Most graduates looking for work is to consider environmental factors and to consider the unit properties, to their jobs are too idealistic, regardless of what can I do, just want to give me anything. Three years in school time more is to accept the classroom education and simulation training, professional development to understand single channel, resulting in ideological concept, to the employment unit work environment, job status, and salary expectations too high.

College Employment Guidance is not Perfect. Nowadays social attention of college students' employment problem is very high, also pay more and more attention to the employment work, set up the employment guidance, information consultation and employment services for the integration of employment guidance center, but the pertinence is not strong.

\section{Promote Oral Medical Students Employment Countermeasure Analysis}

Employment Idea Needs to Change. The external environment impact on university students' employment is to rely on college students to play a role, mainly self-awareness to shift. To let the students set up the correct greatly, first must begin from their own, and always maintain an optimistic and positive attitude to face the employment. Should adjust their own position, face up to their abilities, to oneself have a scientific and reasonable positioning, set up from basic level, starts from the minor matter, starts from the most difficult places, not necessarily immediately to first-tier cities and coastal cities, you can go to small cities across the Midwest development at the grassroots level to their own professional knowledge to practice, to seek greater development stage gradually. It was conducive to the personal development of college graduates and is beneficial to the country's economic and social development.

Shift Training Goal and Talent Training Mode. At present, college graduates can smooth 
employment and entrepreneurship has become a school is one of the main goals of talent training, students learn to complete, the most direct benefit is to be able to smooth employment and entrepreneurship. In order to produce talents to adapt to the current social development, in addition to enhance the level of running school, also needs with social needs, constantly optimize the talent training scheme, introduce the social concept of teaching, also can undertake ordering cultivation, cultivation of high-quality talents to meet the needs of unit of choose and employ persons. Colleges of joint regulation should be strengthened at the same time, make the system perfect, colleges of win-win development, long-term solution to the college students employment situation.

Create a Good Social Atmosphere. With the popularization of higher education, to cope with the increasingly severe employment situation, our government has gradually take positive countermeasures, promote university students' employment. Have issued a series of encouraging guide students to graduate to the central and western regions, rural employment, to work in the post at the grass-roots level, to encourage college students self-employment. In it, western volunteer program has been implemented for many years, early for college students, some stay in the local development. On college students' village official news reports, college teachers are with positive energy, which is a typical case is worth to reference for today's college graduates.

\section{Acknowledgements}

2017 colleges in henan province department of education employment entrepreneurship research topic, project number: JYB2017350

\section{References}

[1] Z.T. Jiang, J. Tao: "Theory of university students' employment present situation and countermeasure research"[J]. Journal of Human Resource Management, Vol. 5(2014), p.291(in Chinese)

[2] F.Q. Zhan: "Current female college students employment disadvantaged and countermeasures study" [J]. Journal of Chifeng University Journal (Chinese philosophy and social science edition), Vol. 35(2014), No.1, p.138-140(in Chinese)

[3] K. Du: 'University students' employment gender discrimination phenomenon in the process of research" $[\mathrm{J}]$. Journal of Guangdong Technical Teachers College (Social Science), Vol.5(2014),p.56-64(in Chinese)

[4] H. Yang: "After 80 female college students' employment situation and gender difference analysis”[J]. Journal of Women's Studies Review, Vol.3(2014),p.30-38(in Chinese)

[5] L. Yu: "Employment psychology to bear ability in the process of higher vocational colleges cultivate"[J]. Journal of Changsha Railway Institute (Social Science Edition), Vol.15(2015), No.4, p.108-109(in Chinese)

[6] C.X. Ye: "Girls in higher vocational colleges employment present situation and the countermeasure analysis"[J]. The Champ, Vol.38(2015), (in Chinese) 